\title{
2010 Frank J. Goodnow Award for Distinguished Service Presented to Martha A. Ackelsberg, Kristen Renwick Monroe, and Rogers M. Smith
}

\section{MARTHA A. ACKELSBERG}

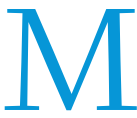
artha A.
A ckels -
berg, William R. Kenan, Jr. Professor of Government, and Program for the Study of Women and Gender, Smith College, has both notably expanded politi-

cal scientists' subjects of study and made a major contribution to the greater diversity, equality, and inclusion of the APSA membership. Through her scholarship, teaching, and service to the profession, she exemplifies the principles reflected in the Goodnow Award.

A pioneer in the development of the academic fields of women and politics and gender studies, Professor Ackelsberg helped revolutionize the discipline to include women, gender, and sexuality as subjects of study. She chaired APSA's Committee on the Status of Women, co-authoring the reports "The Status of Women in Political Science: Female Participation in the Professoriate and the Study of Women and Politics in the Discipline" and "Remembering the Life in Academic Life: Toward a Better Balance Between Work and Personal Life." She also chaired the Women's Caucus and the Gender and Politics section of the Western Political Science Association. Professor Ackelsberg further promoted greater diversity, equality, and inclusion in the APSA by serving on the Committee on the Status of Lesbians, Gays and Bisexuals in the Profession, co-authoring the "Report on the Status of Lesbians and Gays in the Political Science Profession," and on the Lesbian, Gay, and Bisexual Caucus. Colleagues throughout APSA recognized the importance of her work and expressed their confidence in her judgment and institutional vision by electing her as APSA Council Member (1996-98) and Vice-President (2006-07).

As a result of Professor Ackelsberg's efforts, APSA is in a very different place with respect to the inclusion of both women's and LGBTQ issues than it was in the 1970s. Her critical engagement reflects her belief that the APSA is an organization worth her very best efforts, and she has never lost confidence that people of goodwill can bring about change. Her scholarly work and her institutional engagement have helped to transform the APSA into an organization that fosters these intellectual pursuits and nurtures the professional aspirations of a diverse and vibrant membership.

\section{KRISTEN RENWICK MONROE}

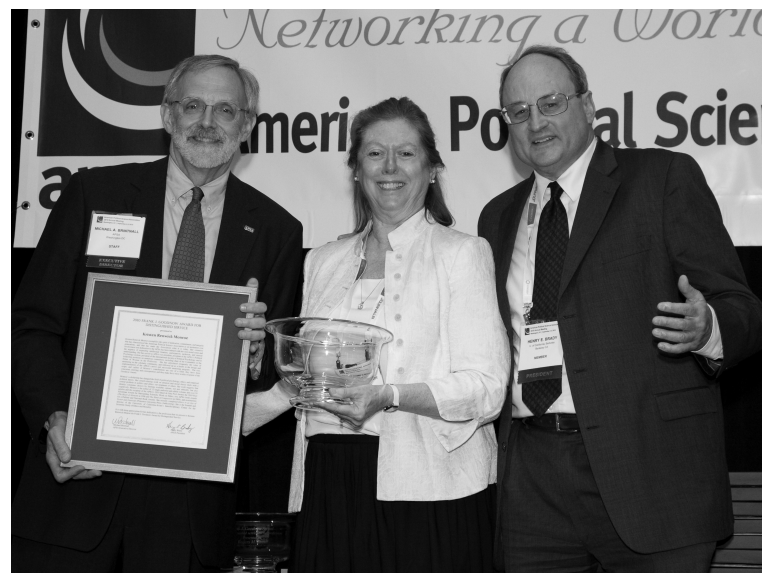

APSA executive director Michael Brintnall (left) and APSA president Henry Brady (right) pose with Kristen Renwick Monroe after she received the Goodnow Award at the Awards Ceremony. Monroe also delivered the Ithiel de Sola Pool lecture.
K

risten Renwick Monroe exemplifies the spirit of dedication, commitment, and integrity that has characterized the APSA as an institution over generations and made the Association what it is today. Her extensive involvement and dedication to the APSA have been imbued with her own moral sense and the urgency of expanding intellectual frontiers, participation, inclusion, and mutual understanding. She has served as APSA vice president, president of the APSA's Political Psychology section, president of the International Society of Political Psychology, and in leadership positions on numerous committees, including chair of the Committee on the Status of Women in the Profession. She has articulated eloquently the value of mentoring in the scholarly community, and followed up as a leader in the design and implementation of the APSA's active and successful mentoring program. The size, scope, and caliber of Monroe's contributions are one of a kind; they have been consistent, unerring, and consequential, and they make her a most worthy recipient of the Goodnow Award.

Monroe's scholarship has changed the field of political psychology, ethics, and empirical political theory. Her award-winning work on altruism and moral choice deals with a central problem in politics and ethics: our treatment of others. Her work suggests that identity constrains choices by limiting available options, not just ethically, but also cognitively. Monroe is the author of 12 singleauthored and edited volumes and over 50 articles, and she is the recipient of the APSA's 2010 Ithiel de Sola Pool Award, the 2010 Paul Silverman Award for Outstanding Scientific Work on Ethics, two APSA book awards (for The Heart of Altruism in 1996 and The Hand of Compassion in 2004), and nominations for a Pulitzer and National Book Awards. She recently completed Ethics in an Age of Terror and Genocide (Princeton University Press, forthcoming). She is the founder and director of the University of California-Irvine's Interdisciplinary Center for the Scientific Study of Ethics and Morality.

\section{ROGERS M. SMITH}

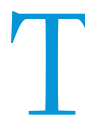
he Frank J. Goodnow Award is presented to Rogers M. Smith, the Christopher H. Browne Distinguished Professor of Political Science at the University of Pennsylvania, for his singular record of service to the profession, scholarship, and contributions to teaching.

His service to the profession is measured by his participation and leadership within the Association. He has served as APSA vice president (2008-09); as a member of the Council (2005-06) and its Administrative Committee (2009); as a member of the APSA Committee on the Status of Blacks in the Profession (2004-07); as co-chair of the APSA Task Force on Graduate Education (2002-03); as president of the Politics and History Organized Section (2001-02); 


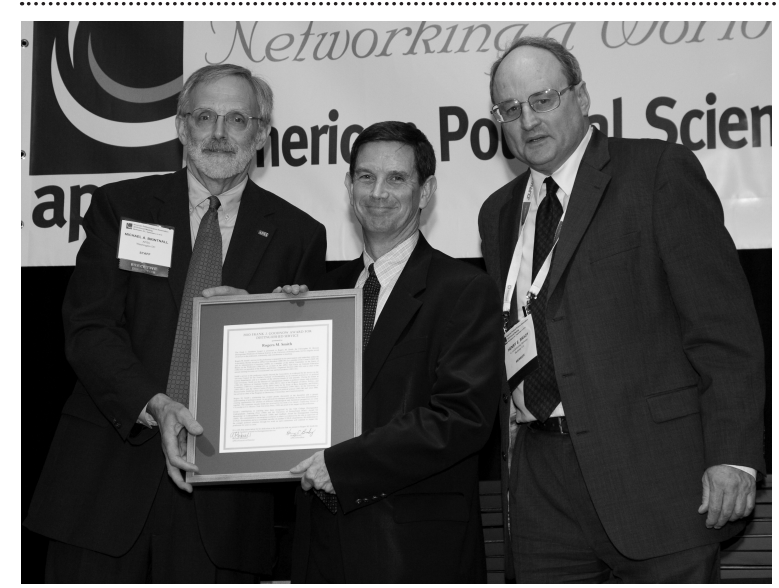

APSA executive director Michael Brintnall (left) and APSA president Henry Brady (right) pose with Rogers M. Smith after he received the Goodnow Award at the Awards Ceremony

and as chair of the Annual Meeting Division on Constitutional Law and Jurisprudence (2001-02).

His service to the profession reaches beyond the Association, as evidenced by his service on the Advisory Council for the Teachers Institute of Philadelphia; as an external reviewer to 12 political science departments; and as a member of the edi- torial boards of nine journals. During his tenure at Yale University, he served as the director of undergraduate studies in political science and economics (1986-88); director of graduate studies (1999-2001); chair of the Program of Ethics, Politics, and Economics (1989-91); codirector of the ISPS Center for the Study of Race, Inequality, and Politics (1995-2001); and the Alfred Cowles Professor of Government (1999-2001). At the University of Pennsylvania, he has been chair of the department of political science (2003-06) and, since 2006, has served as chair of the Program on Democracy, Citizenship, and Constitutionalism.

His scholarship has created greater discussion of the discipline and a greater understanding of political science. As an advocate for dialogue and debate, he has been instrumental in creating opportunities for scholars of different methodological and theoretical perspectives to come together. The numerous awards received for his book Civic Ideals: Conflicting Visions of Citizenship in U.S. History (Yale UP, 1999) are proof of his impact on the profession.

His contributions to teaching have been recognized by the Yale College Distinguished Undergraduate Teaching Prize (1984) and the University of Pennsylvania Dean's Award for Mentorship of Undergraduate Research (2008) and Lindback Award for Distinguished Teaching (2009). His commitment to encouraging excellence in others is evidenced by his role as supervisor of $33 \mathrm{Ph}$.D. dissertations and as a committee member on another 52 Ph.D. dissertations. His dedication to the younger political scientists through his work on such committees will continue to impact the profession for years to come.

It is with deep appreciation for these scholars' dedication to the profession that the APSA presented to them the Frank J. Goodnow Award for Distinguished Service. -

\section{APSA's Organized Sections Distributed Awards at the 2010 Annual Meeting in Washington, DC}

\begin{abstract}
T $\mathrm{n}$ addition to the awards presented at the APSA Awards Ceremony on Thursday, September 2, the following recognitions were announced at the business meetings and receptions of the APSA Organized Sections.
\end{abstract}

\section{SECTION 1: FEDERALISM AND INTERGOVERNMENTAL RELATIONS Daniel Elazar Distinguished Federal- ism Scholar Award}

The Daniel Elazar Distinguished Scholar Award recognizes a lifetime of contributions to the study of federalism and intergovernmental relations.

Award Committee: Jeremy Hall, University of Texas, Dallas, chair; Cheryl Collier, University of Windsor; John Dinan, Wake Forest University

Recipient: Richard Simeon, University of Toronto

\section{Deil Wright Best Paper Award}

The Deil Wright Best Paper Award is pre- sented to the author of the best paper on federalism and intergovernmental relations presented at the last APSA Annual Meeting.

Award Committee: Carolyn Johns, Ryerson University, chair; Shama Gamkhar, University of Texas at Austin; Christopher Borick, Muhlenberg College

Recipient: Jennifer Wallner, University of Regina, Canada

Title: "Does Diversity Always Lead to Decentralization and Difference?"

\section{Martha Derthick Best Book Award}

The Martha Derthick Best Book Award is presented to the author of a book published at least 10 years ago that has made a lasting contribution to the study of federalism and intergovernmental relations.

Award Committee: Kiki Caruson, University of South Florida, chair; Patrick McGuinn, Drew University; Edella Schlager, University of Arizona

Recipient: Paul E. Peterson, Harvard Uni- versity

Title: The Price of Federalism (Brookings Institution Press, 1995)

\section{SECTION 3: LEGISLATIVE STUDIES Alan Rosenthal Prize}

In the spirit of Alan Rosenthal's work, this prize is dedicated to encouraging young scholars to study questions that are of importance to legislators and legislative staff and to conduct research that has the potential application to strengthening the practice of representative democracy. Award Committee: Michele Swers, Georgetown University, chair; Christopher Berry, University of Chicago; John Griffin, Notre Dame University

Recipients: David C.W. Parker, Montana State University, and Craig Goodman, Texas Tech University

Title: "Making a Good Impression: Resource Allocation, Home Styles and Washington Work," Legislative Studies Quarterly 34 (4): 493-524 